\title{
Os 30 ANOS DA CONSTITUIÇÃO: O PAPEL DO DIREITO E DA JURISDIÇÃO CONSTITUCIONAL
}

\author{
THE 30 YEARS OF THE CONSTITUTION: THE ROLE OF \\ THE LAW AND THE CONSTITUTIONAL JURISDICTION
}

\section{LOS 30 AÑOS DE CONSTITUCIÓN: EL PAPEL DEL DERECHO Y DE LA JURISDICCIÓN CONSTITUCIONAL}

Lenio Luiz Streck

\begin{abstract}
1 Introdução. 2 De como o constitucionalismo não morreu. 3 A jurisdição constitucional e a construção de uma adequada teoria da constituição. 4 Da teoria à prática: algumas dificuldades na efetivação do constitucionalismo contemporâneo no Brasil. 5 Conclusão. Referências.
\end{abstract}

\section{RESUMO}

Passados trinta anos da promulgação da sua Constituição, o Brasil se depara com uma grave crise institucional. Neste momento marcante, procuro refletir sobre o Direito (e sua teoria) em nosso país, desde a redemocratização, especialmente sobre o papel que se atribui à jurisdição constitucional e que ela efetivamente desempenha. Reafirmo o papel transformador do constitucionalismo - tanto mais necessário em países com graves problemas estruturais, como o nosso - argumentando que isso não deve ser confundido com ativismo judicial. Na sequência, discuto parâmetros para a jurisdição constitucional e a construção de uma adequada teoria da Constituição. Por fim, volto da teoria à prática, analisando criticamente algumas dificuldades na efetivação do constitucionalismo contemporâneo no Brasil.

Palavras-chave: Constitucionalismo Contemporâneo. Jurisdição Constitucional. Hermenêutica. Ativismo judicial.

* Doutor em Direito pela UFSC e pós-doutor em Direito pela FDUL. Professor titular da Universidade do Vale do Rio dos Sinos (Unisinos/RS) e da Universidade Estácio de Sá (UNESA/RJ). Professor Visitante da Universidade Javeriana de Bogotá, da Universidade de Málaga e da Universidade de Lisboa. Professor emérito da Escola da Magistratura do Rio de Janeiro. Membro catedrático da Associação Brasileira de Direito Constitucional - ABDConst. Presidente de honra do Instituto de Hermenêutica Jurídica (IHJ). Coordenador do Dasein - Núcleo de Estudos Hermenêuticos. Advogado. Ex-Procurador de Justiça do Estado do Rio Grande do Sul. e-mail: <lenio@unisinos.br>.https://orcid.org/0000-0001-8267-7514 


\begin{abstract}
Thirty years after the promulgation of its Constitution, Brazil faces a serious institutional crisis. In this remarkable moment, I try to reflect on the Right (and its theory) in our country, since redemocratization, especially on the role that is attributed to the constitutional jurisdiction and that it effectively plays. I reaffirm the transformational role of constitutionalism - all the more necessary in countries with serious structural problems, such as ours - arguing that this should not be confused with judicial activism. Next, I discuss parameters for constitutional jurisdiction and the construction of an adequate theory of the Constitution. Finally, I return from theory to practice, analyzing critically some difficulties in the realization of contemporary constitutionalism in Brazil.
\end{abstract}

Keywords: Contemporary Constitutionalism. Constitutional Jurisdiction. Hermeneutics. Judicial Activism.

\title{
RESUMO
}

Treinta años después de la promulgación de su Constitución, Brasil enfrenta una grave crisis institucional. En este momento notable, trato de reflexionar sobre el Derecho (y su teoría) en nuestro país, desde la redemocratización, especialmente sobre el papel que se atribuye a la jurisdicción constitucional y que desempeña efectivamente. Reafirmo el papel transformador del constitucionalismo - tanto más necesario en países con graves problemas estructurales como el nuestro - argumentando que esto no debe confundirse con el activismo judicial. A continuación, analizo los parámetros para la jurisdicción constitucional y la construcción de una teoría adecuada de la Constitución. Finalmente, regreso de la teoría a la práctica, analizando críticamente algunas dificultades en la implementación del constitucionalismo contemporáneo en Brasil.

Palabras-clave: Constitucionalismo Contemporáneo. Jusridicción Constitucional. Hermenéutica. Activismo Judicial.

\section{INTRODUÇÃO}

O Brasil de hoje não compreendeu um longo processo de construção de democracia, com destaque para a participação popular, do qual é fruto a Constituição de 1988. Isso ocorre, sobretudo, pela presença facilmente constatável daquilo que denomino de "baixa constitucionalidade”, isto é, a baixa compreensão, que ocorre porque parte da doutrina e da jurisprudência continuam assentadas em dicotomias ultrapassadas.

Isso pode ser demonstrado por posturas do Poder Judiciário que oscilam entre o apego ao texto legal enquanto em outros momentos ignora os seus limites semânticos, ou seja, de um lado, ainda se utiliza uma hermenêutica clássica de cunho reprodutivo; de outro, impera o subjetivismo. Por vezes, em uma mesma decisão, diz-se que está claro o texto legal e, mais 
adiante, a clareza é ignorada. ${ }^{1}$

Tudo isso porque se ideologizou a aplicação do direito: o solipsismo judicial, a partir do que chamo de Privilégio Cognitivo do Juiz - PCJ, submete o ato decisório à vontade do julgador. Também não se pode ignorar que há uma crise no ensino jurídico que impossibilita a comunidade jurídica de compreender que a Constituição tem, por excelência, um papel contramajoritário.

A Constituição serve exatamente para que não caiamos na tentação de apostar em clamor público. A democracia pressupõe a presença do povo no processo decisório, contudo este deve ser garantido mediante espaços reais de presença e de conhecimento sobre quais são os temas essenciais à democracia contemporânea e os limites necessários à sua consolidação.

Na esteira da Crítica Hermenêutica do Direito, ${ }^{2}$ venho trilhando dia a dia um caminho que tem como objetivo a preservação do grau de autonomia do Direito minimamente necessário para que os predadores externos e internos não façam soçobrar o direito legislado, desde que, é claro, esteja em conformidade com a Constituição. Por isso, tenho insistido nos seguintes pontos: Direito não é moral. Direito não é sociologia. Direito é um conceito interpretativo e é aquilo que é emanado pelas instituições jurídicas, sendo que as questões a ele relativas encontram, necessariamente, respostas nas leis, nos princípios constitucionais, nos regulamentos e nos precedentes que tenham DNA constitucional, e não na vontade individual do aplicador.

Nesse sentido, ele possui, sim, elementos (fortes) decorrentes de análises sociológicas, morais etc. No entanto, estas, depois que o Direito está posto - nessa nova perspectiva (paradigma do Estado Democrático de Direito) -, não podem vir a corrigi-lo. Nestes 30 anos, houve - e continua a haver - uma enorme dificuldade de nos libertar dos fantasmas do passado. Em face do predomínio, anterior à Constituição, de um formalismo sustentado no positivismo legalista (clássico), os primeiros anos de vigência da Constituição foram palco de uma invasão de posturas, teses e teorias que visavam a matar o velho inimigo até então identificado: o juiz boca da lei, que representava, no imaginário jurídico, o positivismo que atravessara o século XIX e ingressara no século XX.

1 Nesse sentido, ver a minha análise dos principais julgamentos ao longo desses 30 anos da Constituição Federal de 1988: Streck (2018a).

2 A Crítica Hermenêutica do Direito por mim fundada constitui matriz teórica que, sob os aportes da filosofia (em especial, da filosofia hermenêutica de Heidegger e da hermenêutica filosófica de Gadamer), possibilita a análise crítica do fenômeno jurídico. Esse movimento também sofre influências de Warat no tocante à sua crítica ao senso comum téorico, incorporando ainda a noção de coerência e integridade de Dworkin (2002). Trata-se, portanto, de uma matriz teórica para o direito com fundamentos filosóficos e de teoria do direito. Sob o aspecto metodológico, desenvolve-se sob o prisma do método fenomenológico hermenêutico. O ponto central da adoção dessa metodologia consiste na ruptura com as tradicionais estruturas metodológicas da modernidade, que indicam a ideia de certeza e segurança próprias da matematicidade do pensamento moderno. Em contraposição a isso, o método fenomenológico hermenêutico implica um modo de filosofar, concebendo os caminhos metodológicos como precários e provisórios, ou seja, elementos dos quais não se possui total apreensão e domínio. Em poucas palavras: revolve-se o chão linguístico em que está assentada a tradição, reconstruindo a história institucional do fenômeno. 
O lema passou a ser: "com a nova Constituição, morreu o juiz boca da lei e nasceu o juiz dos princípios". Não haveria mais subsunção. "Sentença vem de 'sentire”, dizia-se aos quatro ventos. O novo tempo passara a ter como protagonista uma coisa chamada "valores", com o fundamento de que, superado o positivismo, agora tínhamos que argumentar para sustentar o juiz protagonista. Claro: desamarrado da subsunção, como que a lembrar os voluntarismos da Escola do Direito Livre ou da Livre Investigação Cientifica, nossa doutrina passou a dar a alforria para a livre criação do Direito, como se a nova Constituição não apontasse exatamente para o contrário: agora, precisávamos fazer cumpri-la, sem que isso significasse "ser positivista" (STRECK, 2010).

As práticas jurídicas de então (ensino, doutrina e jurisprudência) - problemática que se estende até os dias de hoje -, ainda atreladas ao velho imaginário de predominância formalista, misturavam diversas posturas, que mais serviam para justificar o solipsismo judicial. Este, aliás, era o paradoxo, que, todavia, ainda não foi superado: embora a cultura jurídica estivesse contaminada por um formalismo que, de certo modo, reproduzia elementos exegéticos, ao mesmo tempo, mesclava-se com mecanismos despistadores, como o discricionarismo e o livre convencimento, tendo fértil terreno nas escolas instrumentalistas no processo civil (herança do solipsismo de Büllow e dos processualistas que o seguiram) e no inquisitivismo no processo penal.

Tudo isso pode ser traduzido do seguinte modo: a promulgação da Constituição enfrentou uma longa caminhada, cheia de percalços: do formalismo civilista conservador (e autoritário), que insistia em interpretar a Constituição a partir da lei, para uma tardia jurisprudência dos valores (recepcionada, aliás, no marco do velho culturalismo jurídico realeano, não menos conservador e autoritário), que despreza(va) a lei e reduz(ia) a Constituição a valores abstratos. Trocar o velho formalismo por uma Jurisprudência de valores tardia (difícil dizer e aquilatar o estrago feito pelas mixagens das diversas teses e posturas empiristas-voluntaristas que se sucederam pós-1988) contribuiu para que não se consolidasse uma nova teoria da decisão que, rompendo com o privatismo, respeitasse a Constituição como norma (CATTONI, 2016).

Dito de outro modo, promulgada a Constituição, ocorreu uma corrida buscando mecanismos que implementassem um novo "juiz dos princípios" que pudesse "derrotar" o juiz "boca da lei", sem que a doutrina explicasse o que era isso - o princípio (isso é dito até hoje, quando ainda se repete o enunciado performativo de que "princípios são valores"). Parcela majoritária da doutrina mais apostou em seguir o que a jurisprudência passou a dizer; isto é, em vez de prescrever o sentido da normatividade da Constituição, contentou-se em legitimar o uso de um ainda embrionário ativismo que foi forjando-se a partir do início dos anos 90.

Torna-se, portanto, vital a reincorporação de um sentido mais amplo à Constituição. Esta deve manter parcela de sua visão institucionalizada; contudo precisa-se desenvolver uma análise crítica da necessidade de integrar a sociedade à Constituição, conforme as condições impostas por uma sociedade complexa. A Constituição não deve conter uma preocupação absoluta com o Estado, mas ser mais ampla, constituindo também a sociedade. A crise que 
se observa tem (des)constituído o Estado e (des)legitimado o instrumento constitucional como instrumento estabilizador da sociedade a partir de demandas nem sempre internas dos Estados Nacionais.

\section{DE COMO O CONSTITUCIONALISMO NÃO MORREU}

A discussão acerca do constitucionalismo contemporâneo é tarefa que se impõe. Isso porque o constitucionalismo não morreu: as noções de Constituição dirigente, da força normativa da Constituição, de Constituição compromissória, não podem ser relegadas a um plano secundário, mormente em um país como o Brasil, onde as promessas da modernidade, contempladas no texto constitucional de 1988, longe estão de ser efetivadas.

Há que se detectar os problemas que fizeram com que parcela dos dispositivos da CF/1988 não obtivesse efetivação: a prevalência/dominância dos paradigmas aristotélico-tomistas (objetivismo) e o paradigma da filosofia da consciência (subjetivista-solipsista), refratários à guinada linguístico-hermenêutica. Essa resistência - produto dessa mixagem de modelos filosóficos - provocou aquilo que se pode denominar de entificação do ser (sentido) do direito (e sobretudo da Constituição).

Outro problema decorre da não existência de um Estado Social no País, muito embora o forte intervencionismo do Estado (e do direito); também deve ser apontada a prevalência do paradigma liberal-formal (individualista) de direito, mormente pela permanência promíscua de um ordenamento infraconstitucional não filtrado constitucionalmente; por último, podem-se ainda arrolar como fatores que obstaculizam a implementação dos direitos constantes na Constituição o processo de globalização e as políticas neoliberais (de perfil desregulamentador) adotadas por sucessivos governos.

$\mathrm{Na}$ verdade, quando falo em "dispositivos constitucionais não efetivados", quero dizer mais do que isso. Com efeito, há um descumprimento que vai além de uma mera confrontação de caráter paramétrico ou de cotejamento entre legislação infraconstitucional e texto constitucional. Há um imaginário de incumprimento que se forjou à margem daquilo que se pode chamar de "falta de efetividade".

Quando não construímos as condições de possibilidade para a constitucionalização do próprio debate acerca do direito em um país como o Brasil, é porque há um corpus de representações que obstaculiza esse objetivo. No momento em que o Poder Judiciário continua julgando de forma solipsista, como se não houvesse ocorrido o "acontecimento da Constituição”, pode-se dizer que estamos diante de uma crise de paradigmas. Essa crise se sustenta em um imaginário dogmático-positivista: embora a Constituição aponte para um novo direito de perfil transformador, nossos juristas, inseridos nesse senso comum teórico, continuam a "operar" (salas de aula, doutrina e práticas tribunalícias) como se o direito fosse uma técnica, ou seja, uma mera racionalidade instrumental.

Um dos pontos fundamentais, para um melhor entendimento/enfrentamento de toda essa problemática, exige uma discussão acerca do papel do direito (portanto, da Constitui- 
ção) e da justiça constitucional no Estado Democrático de Direito. Nesse sentido, além das necessárias críticas ao paradigma liberal, torna-se importante o enfrentamento, ainda que de forma superficial, das posturas procedimentalistas, que, ao repelirem o paradigma do Estado Social, deixam de lado a noção de Estado Democrático de Direito, que é plus normativo em relação ao paradigma promovedor do Welfare State.

Desse modo, entendo que as perspectivas de realização dos direitos fundamentais sociais não estão esgotadas, e, ao contrário do que pregam, por exemplo, em determinadas circunstâncias, as posturas procedimentalistas, o papel da justiça constitucional não deve restringir-se à (mera) compreensão procedimental da Constituição (o que não implica afirmar, por óbvio, que, por exemplo, Habermas despreze a concretização de direitos sociais-fundamentais); ou seja, enquanto o procedimentalismo - em seus diversos matizes - sustenta que a justiça constitucional não deve ser a guardiã de uma suposta ordem suprapositiva de valores substanciais, entendo que a realização dos direitos fundamentais (e não dos valores, como querem as teorias da argumentação, p.ex.), a pretexto da judicialização da política, não pode ser negada à sociedade.

Por outro lado, ao contrário do paradigma procedimentalista, que entende que a Constituição não deve ser entendida como uma ordem jurídica global e concreta, destinada a impor a priori uma determinada forma de vida sobre a sociedade, sustento que o constitucionalismo, exsurgente do Estado Democrático de Direito, pelo seu perfil compromissário, dirigente e vinculativo, constitui-a-ação do Estado.

Em outras palavras - e para deixar isso bem claro -, entendo que, enquanto não for superado o triângulo dialético de que fala Canotilho (a não resposta adequada do Estado à falta de liberdade e segurança, a permanência da desigualdade política e o não combate à desigualdade social), o papel da força normativa da Constituição nem de longe pode ser considerado como esgotado.

\section{A JURISDIÇÃO CONSTITUCIONAL E A CONSTRUÇÃO DE UMA ADE- QUADA TEORIA DA CONSTITUIÇÃO}

Com as Constituições democráticas do século XX, assume um lugar de destaque outro aspecto, qual seja, o da Constituição como norma diretiva fundamental, que se dirige aos poderes públicos e condiciona os particulares de tal maneira que assegura a realização dos direitos fundamentais-sociais (direitos sociais lato sensu, direito à educação, à subsistência ou ao trabalho). A renovada supremacia da Constituição vai além do controle de constitucionalidade e da tutela mais eficaz da esfera individual de liberdade.

A nova concepção de constitucionalismo une precisamente a ideia de Constituição como norma fundamental de garantia com a noção de Constituição enquanto norma diretiva fundamental (FIORAVANTI, 1998). O caráter inovador assumido pelo constitucionalismo contemporaneamente tem influído poderosamente em determinados aspectos implícitos na 
constitucionalização do direito, podendo ser destacados, com Alonso Garcia Figueroa ${ }^{3}$ (FIGUEROA, 2003, p. 163 e ss), três aspectos: um material, um estrutural e funcional e um político.

O aspecto material da constitucionalização do ordenamento consiste na conhecida recepção no sistema jurídico de certas exigências da moral crítica na forma de direitos fundamentais. Em outras palavras, o direito adquiriu uma forte carga axiológica, assumindo fundamental importância à materialidade da Constituição. $\mathrm{O}$ aspecto material da constitucionalização tem apontado para um reforço entre os juristas de um conceito não positivista de direito, no qual o sistema jurídico está vinculado à moral de forma conceitual, o que, aliás, pode ser um dos elementos que distingue o constitucionalismo atual (neoconstitucionalismo) de suas versões precedentes.

O constitucionalismo tradicional era sobretudo uma ideologia, uma teoria meramente normativa, enquanto o constitucionalismo atual tem-se transformado em uma teoria do direito oposta ao positivismo jurídico enquanto método. Já o aspecto estrutural da constitucionalização do ordenamento tem relação com a estrutura das normas constitucionais. $\mathrm{O}$ aspecto funcional se expressa por meio do tipo de argumentação que estas fomentam. Assumem relevância, nesse contexto, os princípios constitucionais, incidindo sobre o ordenamento e sobre a aplicação do ordenamento. Há um efeito de irradiação provocado pelos princípios, questão que pode ser observada nos tribunais constitucionais europeus e no desenvolvimento da teoria da argumentação jurídica, na medida em que toda interpretação se submete aos princípios.

Assim, aduz Figueroa, se o aspecto material da constitucionalização do ordenamento tem vinculado o direito à moral, o aspecto funcional tem aproximado o raciocínio jurídico do raciocínio moral. Em termos políticos, os aspectos anteriores representam consequências importantes na correlação de forças existente entre os Poderes do Estado. A consequência mais importante tem sido a acentuada transferência do protagonismo do Poder Legislativo em direção à Justiça Constitucional, a ponto de autores como Alexy falarem de uma "omnipotencia dos Tribunais" (Omnipotenz der Gerichte). Esse deslocamento do polo de tensão em direção ao Poder Judiciário (ou à Justiça Constitucional) tem sido considerado por muitos como uma grave lesão ao princípio democrático. Essa circunstância assume maior gravidade em países como o Brasil, em que há um crescente ativismo judicial, regra geral constituindo nada mais do que uma vulgata da judicialização da política.

Em face disso, a pergunta é inevitável: como é possível que juízes (constitucionais ou não), não eleitos pelo voto popular, possam controlar e anular leis elaboradas por um poder eleito para tal e aplicadas por um Poder Executivo também eleito? O princípio da maioria pode ceder espaço para a supremacia da Constituição que estabelece, em seu texto, formas de controle sobre a assim denominada "liberdade de conformação do legislador"?

A resposta a essas indagações tem provocado aprofundados debates. O que importa ressaltar, desde logo, é que a experiência de inúmeras nações tem apontado para o fato de

3 Tem razão Figueroa. Essa circunstância assume maior gravidade em países como o Brasil, em que há um crescente ativismo judicial, regra geral constituindo nada mais do que uma vulgata da judicialização da política. 
que o Estado Democrático de Direito não pode funcionar sem uma justiça constitucional. Guardadas as especificidades dos vários países, a justiça constitucional é condição de possibilidade do Estado Democrático de Direito, questão que vem à tona desde o momento em que se passa a entender que as normas constitucionais são normas dotadas de eficácia, quando se abandona o conceito de Constituição no seu sentido meramente formal e programático.

No paradigma instituído pelo Estado Democrático de Direito, parece não restar dúvida de que houve uma alteração substancial no papel a ser desempenhado pelas Constituições. Seus textos possuem determinações de agir; suas normas possuem eficácia, já não sendo mais lícito desclassificar os sentidos exsurgentes desse plus normativo representado pela ideia de que a Constituição constitui-a-ação do Estado.

Talvez aqui se encaixe uma frase seguidamente repetida por Eros Roberto Grau: no Estado Democrático de Direito, e tomando em conta o conteúdo da Constituição brasileira de 1988, é proibido falar em normas programáticas! (GRAU, 2017).

Mais ainda, é preciso ter claro que o paradigma do Estado Democrático de Direito se liga inexoravelmente à função transformadora que o direito assume. Da ideia de direito como ordenação e até mesmo de promoção, exsurge um papel para o direito que vai muito além da Constituição enquanto mero instrumento para a aferição da parametricidade formal. Isso, a toda evidência, demandou um novo tipo de concepção acerca da jurisdição constitucional, representada pela instituição de tribunais constitucionais, também conhecidos como tribunais ad hoc, aptos a instrumentalizar e dar guarida à materialidade dos textos constitucionais.

O estabelecimento dos tribunais constitucionais ocorre em quatro fases, a saber: os que foram criados no período entre as duas grandes guerras, os originados logo depois da Segunda Guerra Mundial, os criados nas décadas de 70 e, mais recentemente, o grande número de tribunais que surgiu na África e nos países da antiga Cortina de Ferro, que, na sua maioria, adotou a fórmula de tribunais ad hoc. Daí a percuciente observação de Vital Moreira (MOREIRA, 1993, p. 178 e ss), para quem a existência de uma jurisdição constitucional, sobretudo se confiada a um tribunal específico (ad hoc), parece ter-se tornado nos tempos de hoje um requisito de legitimação e de credibilidade política dos regimes constitucionais democráticos.

Por isso, a jurisdição constitucional passou a ser crescentemente considerada como elemento necessário da própria definição do Estado de Direito Democrático, a ponto de, mesmo na França, o país mais tradicionalmente avesso ao controle jurisdicional da constitucionalidade das leis, o Conselho Constitucional originariamente criado para impedir o parlamento de invadir a esfera de poder reconhecido ao governo parece evoluir seguramente no sentido de se transformar em um verdadeiro tribunal constitucional, ao mesmo tempo em que surgem propostas doutrinárias visando a alargar aos tribunais comuns esse poder. Também na Suíça, onde o sistema de fiscalização de constitucionalidade exclui desde sempre o controle das leis do parlamento federal, a comissão de peritos para a revisão global da Constituição recomendou no seu relatório a introdução da fiscalização concreta das leis federais. Até na Grã-Bretanha deixou de ser heresia a ideia de criar uma carta de direitos fundamentais constitucionalmente 
garantida contra o legislador (entrenched bill of rights) e de confiar a sua defesa aos tribunais (MOREIRA, 1993, p. 178 e ss).

Ainda com Vital Moreira, é preciso deixar assentado que os dois dogmas em que tradicionalmente se baseava a contestação à legitimidade da justiça constitucional - soberania do parlamento e separação dos Poderes - deixaram de ter, em grande medida, correspondência na realidade político-constitucional contemporânea. De um lado, a soberania do parlamento e da intangibilidade e onipotência do legislador parlamentário perdeu definitivamente terreno em favor da concepção da soberania e da supremacia da Constituição e do caráter constituído e subordinado do Poder Legislativo, bem como da convicção de que o princípio da maioria não equivale à prepotência nem pode traduzir-se na imunidade do Poder Legislativo e do Executivo perante as violações da lei fundamental. A soberania do parlamento cedeu passo à supremacia da Constituição. $\mathrm{O}$ respeito pela separação dos Poderes e pela submissão dos juízes à lei foi suplantado pela prevalência dos direitos dos cidadãos em face do Estado. A ideia base é a de que a vontade política da maioria governante de cada momento não pode prevalecer contra a vontade da maioria constituinte incorporada na Lei Fundamental.

O poder constituído, por natureza derivado, deve respeitar o poder constituinte, por definição, originário (MOREIRA, 1993, p. 178 e ss). Esse reconhecimento do papel da justiça constitucional torna indispensável reconhecer a necessidade da intervenção de um poder (no caso, o Judiciário ou os Tribunais Constitucionais não pertencentes - stricto sensu - ao Judiciário), mediante o instrumento de controle de constitucionalidade. ${ }^{4}$ Nesse sentido, é preciso analisar e compreender o papel destinado à Justiça Constitucional no confronto com e entre os poderes do Estado, seus limites por meio da jurisdição constitucional, bem como as condições de possibilidade do exercício da assim denominada "liberdade de conformação do legislador" (CANOTILHO, 1982, p. 274).

Desde logo, parece razoável afirmar que a liberdade do legislador é mais restrita quando trata de direitos de liberdade. Já quando se trata de liberdades econômicas, de mercado, ou de prestações sociais (políticas públicas), o leque de opções legislativas (e do Poder Executivo) é nitidamente maior, o que não significa que os atos legislativos e de governo não tenham de estar indissoluvelmente conformados com o texto da Constituição e sua materialidade (HOMMERDING, 2012). Dizendo de outro modo: o Estado Democrático de Direito não admite discricionariedade (nem) para o legislador, porque ele está vinculado à Constituição (lembremos sempre a ruptura paradigmática que representou o constitucionalismo compromissório e social). Entretanto, é bom esclarecer que, no âmbito do legislador, quando afirmo não haver discricionariedade, quero dizer que ele não pode fazer o que quer. Há uma legitimidade política do legislador que lhe permite, no "espaço estrutural-constitucional”, fazer opções. Daí

4 Sobre o papel da justiça constitucional que se firmou no segundo pós-guerra, ver Favoreu (1984, p. 1147 e ss.), que fala de "une redécouverte de la Constitution comme texte à caractère juridique" e da expanção da competência dos tribunais; e Verdú (1957, p. 99 apud SEGADO, 1997, p. 49-50), que sublinhou que "la jurisdicción constitucional de la segunda postguerra nos ofrece como novedad sustantiva un ensanchamiento de su ámbito en la medida que abarca, a la sazón, contenidos no sólo técnicos, sino, además, materiais que rozan aspectos de indudable cariz político". 
a diferença entre o legislador e o juiz. O juiz sempre terá "dúvidas", que podemos chamar de "ontológicas", mas, ao contrário do legislador, ele está vinculado a uma espécie de DNA do direito, formado pela doutrina lato sensu e pela jurisprudência, o que faz com que seja obrigado a obedecer à coerência e à integridade do direito (reconstrução da história institucional). Por isso, o juiz não pode julgar conforme sua "vontade", problemática que será discutida mais amiúde na sequência deste livro.

Isso significa que tais liberdades encontrarão limites na própria normatividade da Constituição, nos direitos nela previstos e nos mecanismos que o próprio texto constitucional estabelece para a sua efetivação. No caso brasileiro, de imediato, vêm à baila institutos como o mandado de injunção e a inconstitucionalidade por omissão (ambos relegados a um plano secundário em face da crise de paradigmas que atravessa o direito brasileiro).

Assim, se o parlamento, eleito por uma maioria, decidir não regulamentar determinado direito previsto na Constituição, pode o Tribunal Constitucional determinar essa regulamentação? Afinal, o que se deve entender com a expressão "conceder-se-á mandado de injunção sempre que a falta de norma regulamentadora...", ou do dispositivo que diz que o Brasil "é uma República que visa a erradicar a pobreza"?

Todas essas questões assumem especialíssima relevância na discussão do próprio Estado Democrático de Direito, mormente a partir do conceito de Constituição compromissária e da força normativa que deve ter o texto constitucional. Entra aqui - repito - a importância da discussão acerca do papel do direito e da Justiça Constitucional no interior do Estado Democrático de Direito, questão que será debatida logo a seguir.

\section{DA TEORIA À PRÁTICA: ALGUMAS DIFICULDADES NA EFETIVAÇÃO DO CONSTITUCIONALISMO CONTEMPORÂNEO NO BRASIL}

No âmbito do Direito Constitucional, foi sendo formatado o constitucionalismo da efetividade, uma mistura de realismo jurídico e altas doses de subjetivismo, dependendo do protagonismo judicial em doses equiparáveis àquilo que Bülow reivindicava dos juízes alemães para a importação do direito romano naquele fim de século XIX. Sem dúvida, era sedutor ver determinados juízes e tribunais assumirem a vanguarda da implementação dos direitos constitucionais, algo que não se via antes da Constituição. Não esqueçamos que, no ancien régime decorrente do Golpe Militar de 1964, os juristas críticos buscavam um acionalismo judicial, a partir de teses alternativistas (baseadas na filosofia da linguagem ordinária e, basicamente ainda que de maneira implícita - nos realismos jurídicos escandinavo e norte-americano) e em teorias marxistas que descontruíam o establishment jurídico-político-dogmático. No entanto, uma vez promulgada a Constituição, esse acionalismo poderia ser prejudicial - como acabou sendo - dependendo do modo como se colocava o papel do Judiciário.

Com efeito, nos primeiros anos, começou a florescer a tese advinda do constitucionalismo alemão e seus derivativos espanhol e português, pela qual uma constituição do tipo compromissório representava um deslocamento do polo de legitimidade em direção ao Ju- 
diciário - esquecendo-se, porém, de toda a história institucional que apontava para o perigo em se apostar em um Judiciário forjado em um imaginário no qual predominantemente se raciocinava a partir da dicotomia "positivismo-jusnaturalismo" ou "juiz boca da lei-juiz dos princípios".

De minha parte, embora concordasse com a tese de que, de fato, havia um deslocamento forte do polo de tensão em favor do Judiciário (ou dos Tribunais Constitucionais), sempre coloquei desconfiança para o protagonismo judicial. Por isso, sempre estive afastado do Direito Alternativo, embora tivesse participado de congressos e seminários tratando da temática (STRECK, 2018b). É evidente que, nos primeiros anos, era necessário absorver esse novo paradigma constitucional e fazer a transição de um imaginário jurídico que desconhecia o significado de Constituição em direção ao Estado Constitucional ${ }^{5}$ (CLEVE, 1995, p. 34-53). Lembremos que, no Regime Militar, tivemos a Carta de 1967 determinada pelos militares e, em 1969, o "golpe dentro do golpe", com a EC n. 1 - outorgada de acordo com o AI-5. Nem sequer havia a disciplina de Direito Constitucional na maioria dos cursos jurídicos. Daí sempre a pergunta que fazia em textos, palestras e salas de aula: como olhar o novo com os olhos do velho? O novo tinha enormes dificuldades de nascer, porque o velho teimava em não morrer.

É induvidoso que, no começo da era pós-88, o velho ranço formalista ainda resistia à aplicação da própria Constituição - como se uma lei infraconstitucional pudesse sobreviver sem uma devida filtragem hermenêutico-constitucional -, problemática bem denunciada nas teses garantistas de Ferrajoli. Vigência não é igual a validade - eis um ponto fulcral de Ferrajoli para derrotar leis anteriores à Constituição. Imagine o leitor o problema em um país como o Brasil, em que, promulgada a Constituição, todos os Códigos eram de décadas atrás (alguns, aliás, ainda em vigor no aniversário dos 30 anos). Lembro que, nos primeiros anos, a metáfora da katchanga real era usada ${ }^{6}$ (STRECK, 2012), por mim, como um remédio para enfrentar as velhas teses formalistas. Em um segundo momento, percebi que essa metáfora poderia estar sustentando, ideologicamente, o protagonismo decorrente do ingresso da vulgata da ponderação, fruto de uma errônea leitura da teoria dos princípios de Robert Alexy.

O mesmo ocorreu com a proporcionalidade, também utilizada - inclusive por mim - para superar a aplicação dedutivista-subsuntiva de dispositivos do Código Penal. Nesse sentido, nos primeiros anos, construí raciocínios estratégicos para, por exemplo, por intermédio de uma proporcionalidade "forçada", considerar não recepcionados dispositivos como a reincidência e a Lei das Contravenções Penais, assim como para aplicar a Lei da Sonegação de Tributos em casos de furto em que não restara prejuízo para a vítima, cuja tese capitaneei junto ao Tribunal

5 Um marco no direito constitucional surgiu com um alerta que Clémerson Cleve fez ao movimento do Direito Alternativo e às demais teorias críticas na primeira metade da década de 90.

6 A estória da Katchanga foi inventada pelo saudoso Luis Alberto Warat. Ele a chamava de "O Jogo da Katchanga". Não falava português: retrabalhou os "escravos de Jô", que jogavam "caxangá". No seu portunhol, virou katchangá e, depois, simplesmente... katchanga. Discuti muito em sala de aula e contei várias vezes a estorinha em conferências. Warat contou a estória para metaforizar (e criticar acidamente) a dogmática jurídica. Afinal, dizia "a dogmática jurídica é um jogo de cartas marcadas"; e, quando alguém consegue entender "as regras", ela mesma, a própria dogmática, tem sempre um modo de superar os paradoxos e decidir a "coisa" ao seu modo. 
de Justiça do RS. Do mesmo modo, sustentei que a pena de furto não podia ser duplicada em face de coautoria, se, ao mesmo tempo, no caso do roubo, o concurso de agentes apenas majorava em um terço a pena.

Quando foi aprovada a Lei n. Lei 10.792, de 1.․12.2003, os acusados eram interrogados sem a presença de defensor. Já bem antes dessa lei, meus pareceres como Procurador de Justiça eram todos no sentido da anulação do feito se o interrogatório havia se dado sem a presença de defensor. Os acórdãos (v.g., da 5. a Câmara Criminal do Tribunal de Justiça do Rio Grande do Sul) que anulavam interrogatórios realizados sem a presença de advogado eram sistematicamente atacados - pelo próprio Ministério Público - via recursos especial e extraordinário; e, registre-se, o Superior Tribunal de Justiça anulou os acórdãos que aplicavam a Constituição (princípio do devido processo legal e ampla defesa), reforçando, assim, a problemática relacionada aos obstáculos à plena implementação dos direitos e das garantias constitucionais. De qualquer sorte, não há notícia de que os manuais de direito processual penal, nesse espaço de vigência da Constituição, tenham apontado, antes da edição da Lei 10.792, na direção de que seria nulo qualquer interrogatório sem a presença do defensor. Mas - e aqui vai a confissão da crise paradigmática - bastou que a nova lei viesse ao encontro da (tênue) jurisprudência forjada inicialmente na 5. ${ }^{\text {a }}$ Câmara Criminal do Tribunal de Justiça do Rio Grande do Sul para que a polêmica - instantaneamente - se dissolvesse no ar. Sendo mais claro: os juristas preferiam não obedecer à Constituição, da qual era possível extrair, com relativa facilidade, o império do princípio do devido processo legal e da ampla defesa; entretanto, com o advento da Lei 10.792/2003, estabelecendo exatamente o que dizia a Constituição, cessaram-se os problemas (claro que alguns processualistas penais continuavam a dizer que essa nulidade era relativa, demorando alguns anos para alterarem sua posição. Em suma, obedece-se à lei, mas não se obedece à lei das leis...!

Enfim, posso dizer que pratiquei o garantismo cotidianamente como modo de implementar a melhor jurisdição possível no contexto de um Judiciário refratário a inovações. Não posso deixar de registrar, também, a tese de que entre o velho e novo se estabeleceu uma crise paradigmática, que denominei, de um lado, de crise do paradigma liberal individualista normativista, e, de outro, no plano da compreensão, de crise dos paradigmas aristotélico-tomista e da filosofia da consciência, problemática sobre a qual me debrucei ao longo dos anos, principalmente no livro Hermenêutica Jurídica e $(m)$ Crise (STRECK, 2013a), hoje em sua 11a. Edição. Com efeito, o garantismo foi, desde o início, um excelente mecanismo para implementar a força normativa da Constituição, aos moldes do que falavam Hesse, Canotilho e Ferrajoli. Já em 1990, eu dizia que garantismo era forma de fazer democracia no e pelo Direito. Anos depois, quando Canotilho disse que a Constituição Dirigente morrera, de imediato, propus que adotássemos uma Constituição Dirigente Adequada a Países de Modernidade Tardia. ${ }^{7}$

7 Ao meu lado, defendendo a tese da Constituição Dirigente, sempre estiveram os professores Martonio Barreto Lima, Gilberto Bercovici e Marcelo Cattoni, além de Marcos Marrafon, Flávio Pansieri, Rafael Tomás de Oliveira, André Karam Trindade, Jacinto Coutinho, Luis Alberto David de Araujo, Fernando Faccuri Scaff, Fábio de Oliveira, Nelson Camatta Moreira e Georges Abboud. Bercovici publicou, inclusive, em coautoria com Luis Fernando 
De todo modo, confesso a enorme dificuldade para superar o acionalismo que buscávamos antes da CF/88 - afinal, o Estado era autoritário, e a estrutura jurídica era produto de um paradigma liberal-individualista (lembro que eu dizia, nos anos 90, que o Brasil era como um micro-ônibus: tem direção hidráulica, ar-condicionado, mas só cabem vinte e cinco pessoas) e ingressar em um patamar no qual passaríamos a depender de uma nova linguagem pública, representada por uma Constituição compromissória e dirigente.

Lembro também que, já nos anos 90, eu repetia um julgado do Tribunal Constitucional da Espanha, do ano de 1981 (STRECK, 2018b, p. 388-389), que determinava que os juízes aplicassem a Constituição. Repetia esse julgado Brasil afora como um mantra, assim como aquilo que Ferrajoli chamava de interpretação em conformidade com a Constituição, que nada mais era do que dizer que uma lei vigente só é válida se estiver em conformidade com a Constituição. Malgrado essa dificuldade de fazer a transição do ancien régime para o Estado Democrático de Direito constante na Constituição, sempre contestei os mecanismos que tornavam o Judiciário um criador de Direito, como se pode ver em minhas incontáveis críticas às sumulas e, depois, às súmulas vinculantes.

É possível dizer que, já na metade dos anos 90, os sintomas desse neoprotagonismo começaram a aparecer. Não no sentido de uma efetiva judicialização da política, mas, sim, na implementação de ativismos judiciais. Como é sabido, um dos problemas da doutrina constitucional e da própria jurisprudência é não fazerem, até hoje, a devida distinção entre ativismo e judicialização, o primeiro sempre deletério e prejudicial à democracia, porque behaviorista, e o segundo sempre contingencial, dependendo de competências e incompetências dos demais poderes. Isso me levou à elaboração de uma fórmula - confesso, um pouco tardia, (todos temos certa dose de culpa no florescimento do ativismo) - para firmar essa distinção, que pode ser feita a partir das três perguntas que um juiz-tribunal deve fazer: se está diante de um direito fundamental com exigibilidade, se o atendimento a esse pedido pode ser, em situações similares, universalizado - quer dizer, concedido às demais pessoas - e se, para atender àquele Direito, está-se ou não fazendo uma transferência ilegal-inconstitucional de recursos, que fere a igualdade e a isonomia. Com essas três perguntas, será possível verificar se o ato judicial é ativista ou está apenas realizando, contingencialmente, a judicialização da política. Sendo uma das três perguntas respondida negativamente, estar-se-á, com razoável grau de certeza, em face de uma atitude ativista.

Como dizia a Rainha Vermelha, de Alice no País das Maravilhas, é preciso correr muito para ficar no mesmo lugar. Com efeito, como tudo no Brasil chega tardiamente, sobrevinda a Constituição, em um primeiro momento, foi necessário desmi(s)tificar as posturas formalistas ainda sustentadas no positivismo clássico, o tradicional juiz boca da lei. No entanto, isso não estava claro no âmbito da dogmática jurídica. Aliás, até hoje, nas salas de aula, em parcela da doutrina e nas práticas jurisprudenciais, ainda se pensa que positivismo é igual a juiz boca da

Masseneto, uma denúncia sobre o papel invertido do constitucionalismo dirigente no Brasil, em artigo intitulado A constituição dirigente invertida: a blindagem da Constituição Financeira e a agonia da Constituição Económica. Revista da Faculdade de Direito da Universidade de Coimbra. URI: http://hdl.handle.net/10316.2/24845 
lei. Esquecem-se de que o próprio Kelsen (2009) foi um positivista pós-exegético, olvidam o que foi produzido pelos positivistas pós-hartianos ${ }^{8}$, que apontaram suas baterias para longe do velho exegetismo - isso porque o positivismo da era pós-Hart já não obriga(va) os juízes (STRECK, 2017a). Porém, os juristas brasileiros (e falo apenas destes para não criar incidentes internacionais) não se deram conta desse "pequeno" detalhe, porque continua(ra)m a pensar que positivismo é(era) cumprir a letra da lei.

Talvez por causa desses detalhes nebulosos seja que, em um segundo momento, parte da doutrina se enebriou com certas teorias argumentativas e com uma vulgata da ponderação - o que provocou um verdadeiro estado de natureza interpretativo -, tornando necessário, então, que os juristas críticos começassem a elaborar críticas aos diversos voluntarismos. Dito de outro modo, a crítica do Direito não poderia ser uma crítica fora de ordem. Tão grave é essa questão que, passados os 30 anos, ainda há forte resistência à tese de que os juízes não possuem livre convencimento. O CPC de 2015 - por minha direta intervenção no Parlamento - expungiu a palavra "livre" e, mesmo assim, parcela considerável dos processualistas continua a sustentar o livre convencimento. Circunstância que também se faz presente na própria Suprema Corte, conforme é possível verificar no comentário ao julgamento do caso da AP 470.

Mas a gravidade chega ao patamar de dramaticidade, uma vez que o projeto do CPP de 2010 insistiu na tese de que o juiz tem livre apreciação da prova - o que se repetiu no projeto apresentado, em 2018, na Câmara dos Deputados. Nesse sentido, parece grande o déficit da dogmática processual penal (assim como da dogmática processual civil, que continua a insistir na subjetivista e na voluntarista tese do poder de livre convencimento).

O protagonismo judicial foi se tornando cada dia mais intenso. As fragilidades do presidencialismo de coalizão (Abranches) foram ajudando a tornar o judiciário cada vez mais proativo, passando a ditar "políticas" de forma ad hoc, sem a devida preocupação com os requisitos da judicialização, dentro da diferença entre esta e o ativismo. Já publiquei um texto (STRECK, 2013b, p. 207-222) sobre judiciariocracia de coalizão, em que explico que, do mesmo modo como o Presidencialismo brasileiro é de coalizão, enredado em atendimentos de pleitos políticos ad hoc, circunstância que causa enormes problemas para a assim denominada "governabilidade", também o Supremo Tribunal Federal acaba ingressando perigosamente nesse terreno de (atendimento a) demandas de grupos. Também - e isso precisa ser dito - demandas provenientes da falta de resolução dos problemas das liberdades públicas no plano dos demais tribunais do país. Eles falham, e tudo acaba no STF. Ele cresce. Mas sofre e sangra na legitimidade. Assim como a Presidência da República tem de atender aos pleitos dos partidos, o STF, durante esses mais de vinte anos, acabou por engendrar uma espécie de “julgamentos políticos".

Isso está diretamente ligado a outro ponto: se, ao lado do realismo e dos diversos voluntarismos (aqui incluída a ponderação à brasileira e a má compreensão acerca do positivismo), formos eleger outro aspecto que determinou a fragilização da Constituição (e, portanto, do Direito), não

8 Para fins de aprofundamento, ler Hart (2012). 
podemos deixar de fora a repristinação do dualismo metodológico predominante no século XIX que adentrou o século XX e está presente nestes dias. Esse fenômeno esteve presente no conceito de mutação constitucional de Laband e Jellinek (Verfassungsänderung und Verfassungswandlung, Berlim, 1906) e mereceu mais tarde conhecidos desenvolvimentos por Hsu Dau-lin (Die Verfassungswandlung, Leipzig, 1932) (CATTONI, 2017). Nesse sentido, como bem afirmam Artur J. Jacobson (New York) e Bernhard Schlink (Berlim), em sua obra Weimar: a jurisprudence of crisis (JACOBSON, 2000, p. 45-46), o dualismo metodológico - positivismo legalista-positivismo sociológico -, que perpassa toda a obra de Jellinek (JELLINEK,1906) e que serve de base para a tese da mutação constitucional (Verfassungswandlung), impediu o jurista alemão de lidar normativamente com o reconhecimento daquelas que seriam "as influências das realidades sociais no direito". A mutação constitucional é assim tida como fenômeno empírico, que não é resolvido normativamente: "Jellinek não apresenta um substituto para o positivismo legalista, mas apenas tenta suplementá-lo com uma análise empírica ou descritiva dos processos político-sociais." (JACOBSON, 2000, p. 46 e 54-57). Na verdade, o conceito de mutação constitucional mostra apenas a incapacidade do positivismo legalista da velha Staatsrechtslehre do Reich alemão de 1870 em lidar construtivamente com a profundidade de sua própria crise paradigmática.

Mesmo em Hsu-Dau-Lin e sua classificação "quadripartite” do fenômeno da mutação constitucional $^{9}$, não se leva em conta aquilo que é central para o pós-segunda guerra e, em especial, para a construção do Estado Democrático de Direito na atualidade: o caráter principiológico do direito e a exigência de integridade que esse direito democrático expõe - muito embora, registre-se, Lin, discípulo de Rudolf Smend, tenha tido a sua disposição a obra de Hermann Heller, um dos primeiros a falar em força normativa da Constituição (nele está o nascedouro da Constituição como norma jurídica). ${ }^{10}$ Smend, embora também tenha trabalhado a noção de princípios, era, assim como Schmitt, admirador do fascismo, como, aliás, Kelsen (2009) muito bem mostrou na crítica brilhante que este fez à teoria do Estado como integração.

Observe-se que essa fenomenologia parece tratar do que ocorreu e continua ocorrendo no Brasil - e isso pode ser percebido em parcela considerável dos 30 casos escolhidos para compor esta obra: coloca-se uma contraposição da realidade social à normatividade constitucional. A opção parece que tem sido, predominantemente, pela primeira. Em síntese, a tese dualista herdada de Laband e Jellinek justifica, passados mais de um século, uma concepção

9 De todo modo, lembremos que Hsu dau-Lin escreveu o seu texto no contexto da República de Weimar, havendo todo um debate sob a Lei Fundamental, por exemplo, com Konrad Hesse e Böckenförde.

10 Nessa genealogia acerca da transição de CF/88 para os anos posteriores, é de perguntar se os primeiros anos da Lei Fundamental alemã também não foram ainda marcados pelos discípulos de Schmitt e Smend (aí sim) nas universidades, ou seja, vai demorar um pouco ainda para a chegada da hermenêutica de Hesse e Kriele, do patriotismo da Constituição de Steinberger e mais tarde de um crítico da jurisprudência dos valores como é Friedrich Müller e sua teoria estruturante. Talvez esse fenômeno tenha se repetido no Brasil, claro que em uma dimensão maior, pela demora de se incorporar a ideia de que Constituição é norma, problemática que, passados 30 anos, continua a mostrar as suas extremas fragilidades, em face da presença das mais variadas teses subjetivistas, realistas, empiristas lato sensu, pelas quais "princípios são valores" e o protagonismo do judiciário não encontra limites nem na estrutura do texto constitucional. 
decisionista da jurisdição e contribui para a compreensão das cortes constitucionais como poderes constituintes permanentes (HORTA, 2002, p. 104-105; VERDÚ, 1984, p. 179-180).

Assim, todos os grandes julgamentos incorporaram essa dualização, propiciando que uma dita realidade social se sobrepusesse à realidade normativa. Assim foi no Mensalão, na Operação Lava-Jato (e os recursos judiciais decorrente de seus julgamentos) e no caso das diversas ações envolvendo aquele que é o maior julgamento destes 30 anos: a presunção da inocência e sua redefinição a partir do HC 126.292, ocasião pela qual o STF ignorou a literalidade do artigo 283 do CPP sem, no entanto, declará-lo inconstitucional. Essa problemática se arrasta por mais de dois anos, incluindo três ações declaratórias de constitucionalidade.

Não somente a Suprema Corte, mas também as demais instâncias do Judiciário e do Ministério Público, aos poucos, foram institucionalizando uma disputa entre o Direito e a moral, tendo dado ganho de causa aos argumentos morais. Há vários julgamentos que comento nesta obra em que essa questão aparece claramente, como os casos que envolveram a Lei da Ficha Limpa, a perda de mandatos parlamentares, o Mensalão, a presunção da inocência, entre outros tantos, com um relevante detalhe: até mesmo nos casos em que a questão constitucional se apresentava como um easy case, houve pronunciamentos invocando ponderações inexistentes.

\section{CONCLUSÃO}

Nestes 30 anos da Constituição, ainda há um déficit considerável acerca do verdadeiro papel do rule of law. As faculdades de Direito colaboraram enormemente para que o ensino do Direito viesse a ser substituído por péssimas teorias políticas do poder. Resultado: na hora em que precisamos de resistência constitucional, o debate é tomado por posições ideológicas, em que soçobra(ra)m as garantias constitucionais, mormente no âmbito do processo penal. Com efeito, além de invocações de argumentos morais, políticos e econômicos, parcela considerável dos tribunais ainda inverte o ônus da prova nas ações penais; sequer conseguimos implementar o artigo 212 do CPP, por uma equivocada compreensão acerca do sentido do que seja um sistema acusatório.

Uma questão, portanto, que marca estes 30 anos pode ser resumida do seguinte modo: Quando um magistrado diz que julga "conforme sua consciência” ou julga "conforme o justo" ou "primeiro decide e depois vai encontrar um fundamento" ou ainda "julga conforme os clamores da sociedade”, é porque está repetindo algo enraizado no imaginário jurídico. Um comportamento que se naturaliza leva muitos anos para "desnaturalizar". Transforma-se em dogmática, eliminando o tempo e as coisas (cronofobia e factumfobia). O que ocorre é que não queremos admitir que ideologizamos - para usar uma palavra suave - a aplicação da lei no país. Isso é facilmente verificável no conjunto de decisões que analisamos aqui. Daí a pergunta que deve ser respondida: o Direito, ao fim e ao cabo, é o que dele se diz por aí ou, melhor, ele é o que o Judiciário diz que ele é? Mas se isso é assim, se já se "naturalizou” essa concepção, por que continuamos a estudar ou escrever sobre o Direito? Não seria melhor deixar que "quem decide é quem sabe"? 
Nós, brasileiros não temos certeza se (já) atravessamos o Rubicão. São 30 anos de Constituição, em que dia a dia os predadores - endógenos e exógenos ${ }^{11}$ - avançam em direção à cidadela do Direito. Enquanto as democracias europeias se deram conta de que o Direito pós-bélico necessitava de um elevado grau de autonomia do Direito - afinal, o grande mote foi "Constituição (agora) é norma" -, por aqui, o Direito continuou a ser tratado como uma mera racionalidade instrumental. Isso é possível de perceber pelo crescimento vertiginoso das teorias ou posturas empiristas - da qual a mais perigosa é o realismo jurídico, não devendo, todavia, ser desprezadas as posturas que se baseiam em análises econômicas do Direito e as teses que admitem o discricionarismo e pamprincipiologismos, que chegaram ao ápice quando um princípio como "afetividade", para falar apenas deste, derrota uma regra do Código Civil.

Sempre fazemos jurisdição constitucional. Uma lei só é lei se for constitucional. Logo, é um exercício pleno e efetivo de jurisdição constitucional. Mesmo quando praticamos os clássicos critérios de antinomias, trabalhamos a partir de princípios e preceitos constitucionais, como igualdade, legalidade, isonomia, etc. Venho desenvolvendo essas temáticas nestes 30 anos de nossa Lei Maior, a partir do que denominei, de há muito, de Crítica Hermenêutica do Direito. Por ela, devemos revolver o chão linguístico em que está assentada a tradição e reconstruir a história institucional de cada instituto (lei, princípio, etc.), descascando o fenômeno, para permitir que ele se mostre em sua inteireza hermenêutica. Os conceitos jurídicos - e não é difícil perceber isso - vão sendo tomados por uma poluição semântica. Ao lado disso, existe o perigo da anemia significativa (Warat). Isso aconteceu com o conceito de presunção da inocência, que foi sendo corroído por argumentos morais, dilacerando sua própria positividade.

Daí a necessidade de resistir. Defender a legalidade constitucional - conceito que aprendi há décadas com o grande constitucionalista espanhol Elias Diaz - 7é, no aniversário destes 30 anos, um ato revolucionário, a ponto de poder afirmar que o professor de Direito Constitucional é, hoje, um subversivo, se trabalhar, efetivamente, com a força normativa da Constituição. Esse professor, se estiver acompanhado de outros pesquisadores (quatro ou mais), corre sempre o risco de ser processado pelo crime de obstrução epistêmica da justiça. Parafraseando T. S. Eliot - para quem, em um país de fugitivos, quem anda na contramão parece que está fugindo -, permito-me dizer que, em um país de voluntaristas e realistas, quem defende a legalidade é taxado de "positivista" - o que não apenas significa ignorância, como também um sintoma dos efeitos deletérios que uma má teoria do direito provocou, e continua provocando, no seio do Direito brasileiro.

11 Ao lado dos predadores exógenos - política, moral e economia -, temos os predadores endógenos, internos, que são o poder discricionário dos juízes, o livre convencimento, a livre apreciação da prova, os diversos modos de enfraquecimento da coisa julgada, o uso precário da jurisdição constitucional, os próprios embargos declaratórios (que acabam sendo um remédio contra decisões mal fundamentadas), o modo como nós fazemos o filtro dos recursos e vamos trabalhando muito mais com efetividades quantitativas em vez de qualitativas. Esse conjunto de elementos vai enfraquecendo internamente o Direito. 


\section{REFERÊNCIAS}

CANOTILHO, J. J. Gomes. Constituição dirigente e vinculação do legislador. Coimbra, Coimbra Ed., 1982.

CATTONI, Marcelo Andrade de Oliveira. Processo Constitucional. 3. ed. Belo horizonte: Fórum, 2016.

CATTONI, Marcelo Andrade de Oliveira. Contribuições para uma Teoria Crítica da Constituição. Belo Horizonte: Arraes, 2017.

CLEVE, Clémerson. A teoria constitucional e o direito alternativo (para uma dogmática constitucional emancipatória). In: Carlos Henrique de Carvalho Filho (org.). Uma vida dedicada ao Direito. Homenagem a Carlos henrique de Carvalho. O editor dos juristas. São Paulo: Revista dos Tribunais, 1995.

DWORKIN, Ronald. Levando os Direitos a Sério. Tradução Nelson Boeira. São Paulo: Martins Fontes, 2002.

FAVOREU, Louis. Actualité et legitimité du contrôle juridictionnel des lois en Europe Occidentale. Revue du Droit Public et de la Science Politique, n. 5, set./out. 1984.

FIGUEROA, Alfonso Garcia. La teoría del derecho en tiempos de constitucionalismo. In: CARBONELL, Miguel (ed.). Neoconstitucionalismo(s). Madrid: Trotta, 2003.

FIORAVANTI, Maurizio. Los derechos fundamentales. Madrid: Trotta, 1998.

GRAU, Eros. Por Que Tenho Medo Dos Juízes. 8. ed. São Paulo: Malheiros, 2017.

HART, H. L. A. O Conceito de Direito. Pós-escrito organizado por Penelope A. Bulloch e Joseph Raz. Tradução Antônio de Oliveira Sette-Câmara. São Paulo: WMF Martins Fontes, 2012 .

HOMMERDING, Adalberto. Teoría de la legislación y derecho como integridad. Curitiba: Juruá, 2012.

HORTA, Raul Machado. Direito Constitucional. Belo Horizonte: Del Rey, 2002.

JACOBSON, Artur J.; SCHLINK, Bernhard. A jurisprudence of crisis. Berkeley: University of California, 2000.

JELLINEK, Georg. Verfassungsänderung und Verfassungswandlung. Berlim: Häring, 1906.

KELSEN, Hans. Teoria Pura do Direito. Tradução João Baptista Machado. 8. ed. São Paulo: WMF Martins Fontes, 2009. 
MOREIRA, Vital. Princípio da maioria e princípio da constitucionalidade. In: BRITO, j. Sousa e et al. Legitimidade e legitimação da justiça constitucional. Coimbra: Coimbra Ed., 1993.

SEGADO, Francisco Fernandez. Evolución histórica y modelos de control constitucional. La jurisdicción constitucional en Iberoamerica. Madrid: Dykinson, 1997.

STRECK, Lenio Luiz. Uma análise sociológica do direito. Entrevista com Lenio Streck. Instituto Humanitas UNISINOS, São Leopoldo, 24 ago. 2009. Disponível em: http:// www.ihuonline.unisinos.br/index.php?option $=$ com_content $\&$ view $=$ article $\& i d=2758 \&$ sec ao=305. Acesso em: 15 ago. 2018.

STRECK, Lenio Luiz. Aplicar a "Letra da Lei" é uma atitude positivista?. Novos Estudos Jurídicos, v. 15, p. 158-173, 2010.

STRECK, Lenio Luiz. A Katchanga e o bullying interpretativo no Brasil. Consultor jurídico, São Paulo, 28 jun. 2012. Disponível em: https://www.conjur.com.br/2012-jun-28/ senso-incomum-katchanga-bullying-interpretativo-brasil. Acesso em: 15 ago. 2018.

STRECK, Lenio Luiz. Hermenêutica Jurídica e(m) Crise: uma exploração hermenêutica da construção do Direito. 11. ed. Porto Alegre: Livraria do Advogado, 2013 a.

STRECK, Lenio Luiz. Democracia, Jurisdição Constitucional e Presidencialismo de Coalizão. Observatório da Jurisdição Constitucional, v. 6, n. 1, p. 207-222, maio 2013b.

STRECK, Lenio Luiz. "Abandonar as próprias vontades é o custo da democracia" [entrevista]. Consultor jurídico, 10 ago. 2014. Disponível em: https://www.conjur.com.br/2014-ago-10/ entrevista-lenio-streck-jurista-advogado-procurador-aposentado. Acesso em: 15 ago. 2018.

STRECK, Lenio Luiz. Dicionário de Hermenêutica - os quarenta temas fundamentais da teoria do direito. Belo Horizonte, Editora Casa do Livro, 2017a.

STRECK, Lenio Luiz. Verdade e Consenso: Constituição, Hermenêutica e Teorias Discursivas. 6. ed., revista e ampliada. São Paulo: Saraiva, 2017 b.

STRECK, Lenio Luiz. 30 anos da CF em 30 Julgamentos: uma radiografia do STF. Rio de Janeiro: Editora Forense, 2018a.

STRECK, Lenio Luiz.. Jurisdição Constitucional. 5. ed. Rio de Janeiro: Forense, 2018b.

VERDÚ, Pablo Lucas. Curso de derecho político. Madrid: Tecnos, 1984. v. 4.

VERDÚ, Pablo Lucas. Problemática actual de la justicia constitucional y del examen de constitucionalidad de las leyes. Boletin Informativo del Seminario de Derecho Político, Universidad de Salamanca, maio/out. 1957. 